Curr Opin Nephrol Hypertens. 2009 July ; 18(4): 281-284. doi:10.1097/MNH.0b013e32832b5094.

\title{
Phosphate Sensing
}

\author{
Rajiv Kumar \\ Division of Nephrology and Hypertension, Departments of Medicine, Biochemistry and Molecular \\ Biology Mayo Clinic and Foundation, 200 First Street SW, Rochester, MN 55902, USA
}

\begin{abstract}
Purpose of review-To discuss findings suggesting the presence of a phosphate sensing mechanism in the various organs and the presence of a novel intestinal effector that alters renal phosphate excretion after the ingestion of a phosphate-containing meal.

Recent findings-Although phosphate homeostasis is controlled by a variety of hormones (such as parathyroid hormone and 1, 25 dihydroxyvitamin D), peptides (the phosphatonins -- FGF-23, sFRP-4, MEPE) and small molecules (dopamine) which regulate the efficiency of phosphate absorption in the intestine and phosphate excretion in the renal tubule, recent data suggest that postcibal changes in renal phosphate excretion following a meal containing phosphate, are mediated by signals generated within the intestine that alter the efficiency of phosphate excretion in the kidney. The intestine detects luminal phosphate and signal to the kidney via the release of the mediator that increases renal phosphate excretion.
\end{abstract}

Summary-Such information would imply the existence of a phosphate sensing mechanism within the intestine and the presence of intestinal factors that influence renal phosphate handling.

\section{Keywords}

Vitamin D; PTH; phosphatonins; phosphate sensors

\section{Introduction}

Phosphate is important in several biological processes ranging from energy homeostasis, cell signaling, membrane integrity to bone mineralization [1]. A variety of mechanisms have evolved to increase the efficiency of phosphate retention in states of phosphate deficiency, and conversely, to decrease retention in states of phosphate excess. Clearly, a necessary first step in the regulation of phosphate homeostasis is the ability of a cell or organism to sense changes in phosphate concentrations in its environment. This would imply the existence of a sensor within or on the surface of cells that is able to detect changes in the concentration of phosphate. In this review I will present information that is consistent with evidence for such a phosphate sensing mechanism in mammals and humans. I will also review information about mechanisms by which prokaryotic and eukaryotic unicellular organisms respond to phosphate.

\section{Rapid and long-term adaptations to changes in dietary phosphate; factors/ hormones that regulate phosphate homeostasis in mammals}

The intestine and kidney are important in the absorption, reabsorption and excretion of phosphate [1]. The vitamin D endocrine system, particularly $1 \alpha, 25$-dihydroxyvitamin D, increases the efficiency of phosphate absorption in the intestine [2-4]. Parathyroid hormone 
(PTH), and the phosphatonins (fibroblast growth factor 23 (FGF-23), secreted frizzled related protein-4 (sFRP-4), matrix extracellular phosphoglycoprotein (MEPE), FGF-7), as well as a variety of other factors such as dopamine, renal nerve activity, and acid base status, influence the excretion of phosphate in the renal tubule [1]. The reviewer is referred to recent publications by our laboratory concerning the interactions amongst these various factors and their role in controlling intestinal phosphate absorption or renal phosphate excretion [1,5-7].

It is important to conceptualize the regulation of phosphate transport in terms of rapid, shortterm changes that occur within a short period after the ingestion of a phosphate-containing meal and those that occur over the long-term in association with chronic changes in the dietary intake of phosphate. It is very likely that the short-term changes are mediated by processes that are distinct from those required for more long-term adaptations to changes in dietary phosphate. Immediately following a meal containing phosphate, rapid alterations in the renal excretion of phosphate occur that are not associated with substantial changes in the vitamin D endocrine system, parathyroid hormone, or the phosphatonins [8]. Also, the feeding of humans and experimental animals diets containing large amounts of phosphate over a period of weeks is associated with modest changes in the vitamin $\mathrm{D}$ endocrine system, parathyroid hormone and the phosphatonins [7,9]. Adaptations to a low phosphate diet can occur in the absence of the vitamin $\mathrm{D}$ receptor. Segawa and colleagues have demonstrated that increases in the expression of the sodium-phosphate cotransporter IIB, which plays a role in the intestinal phosphate transport, occur when vitamin D receptor knockout mice are fed a low phosphate diet [10]. This would imply that the intestine is capable of responding to low dietary phosphate levels by up-regulating phosphate transport independent of 1,25 dihydroxyvitamin $\mathrm{D}$. The intestine has been recently shown to contain a factor or factors that alter the renal excretion of phosphate [11]. Such information suggests the presence of an enteric-renal signaling axis for phosphate, and also implies the existence of a mechanism by which the intestine detects changes in luminal phosphate.

\section{Cells respond to changes in phosphate concentrations in their environment independent of known phosphate regulatory hormones}

Bacterial cells and the unicellular yeast, Saccharomyces cerevisiae are able to detect changes in phosphate concentrations in the environment and appropriately increase the retention or rejection of phosphate [12-16]. In E. coli, periplasmic proteins (PstS, PstC, Pst and, and PstB in association with PhoU) detect low concentrations of inorganic phosphate in the environment and increase the efficiency of phosphate retention by the bacterial cells [13]. When phosphate concentrations are limiting, phosphorylation of histidine residues on the protein, PhoR, is increased. Phospho-PhoR, in turn, phosphorylates the protein PhoB on aspartate residues. Phospho-PhoB is a transcription factor that binds specific DNA sequences (so-called PHO boxes) to increase the transcription of genes in the Pho regulon. Proteins encoded by DNA sequences within the PHO regulon allow the organism to adapt to reduced phosphate concentrations. When phosphate concentrations are adequate, PhoR is de-phosphorylated and no longer phosphorylates $\mathrm{PhoB}$, which in its un-phosphorylated state is incapable of binding to $\mathrm{PHO}$ boxes in the PHO regulon.

In Saccharomyces cerevisiae, reduced phosphate concentrations in the environment results in the in-activation of the Pho80-Pho85 by the cyclin--dependent kinase inhibitor, Pho81 [16]. As a consequence, the transcription factor Pho4 is un-phosphorylated and active, leading to the induction of PHO genes, one of which encodes a protein, Pho84 that functions as a highaffinity phosphate transporter. When phosphate is no longer limiting, Pho84 is degraded and the transcription factor, Pho4, is phosphorylated and exported from the nucleus to the cytoplasm thereby turning off the expression of PHO genes. 
In unicellular organisms, the responses to altered phosphate in the environment have been well characterized. It is unclear as to whether a single molecule acts as the sensor for phosphate on the surface of the cell or whether many of the observed changes in gene expression occur as a result of altered intracellular phosphate concentrations.

\section{Cultured mammalian cells and parathyroid hormone organ cultures respond to extracellular phosphate concentrations}

There is evidence that renal and intestinal cells are capable of responding to changes in phosphate concentrations in their environment. For example, incubating cultured renal epithelia in the presence of either a high or low phosphate concentration rapidly changed the efficiency of phosphate uptake by cells [17]. A low phosphate medium increased phosphate uptake, whereas a high phosphate medium decreased phosphate uptake. There is also evidence that intestinal cells respond to changes in medium phosphate concentrations by increasing phosphate transport $[10,18,19]$. Non-epithelial cells such as osteoblasts and marrow stromal cells also respond to changes in phosphate concentrations in the medium by altering the expression of growth factors, the localization of transcription factors and the secretion of various enzymes [10,18-22]. This would suggest the presence of phosphate sensors within mammalian cells.

Freshly excised parathyroid glands respond to high phosphate concentrations in the surrounding medium. Almaden and colleagues incubated freshly isolated rat parathyroid glands in a media with varying phosphorus concentrations [23-25]. In the presence of 1.25 $\mathrm{mM}$ calcium, parathyroid hormone secretion rates were 3- and 4-fold higher in the presence of 3 and $4 \mathrm{mM}$ phosphate in comparison to 1 or $2 \mathrm{mM}$ phosphate. In the presence of $4 \mathrm{mM}$ phosphate, calcium had a less inhibitory effect on parathyroid hormone secretion than in the presence of 1 or $2 \mathrm{mM}$ phosphate. These data are consistent with the ability of parathyroid glands to respond to phosphate concentrations independent of calcium. Parathyroid cell growth and arachadonic acid metabolism were also affected by phosphate.

\section{Phosphate sensing in vivo}

Recently, several laboratories have published information suggesting the presence of phosphate sensors in experimental animals. Martin and colleagues have suggested the presence of a phosphate sensing mechanism in the parathyroid gland [26]. These investigators fed uremic animals a high phosphate diet for one month, and on the day of the experiment, administered the rats a low phosphate diet. A reduction in serum concentrations of parathyroid hormone was observed within two hours. In this experiment, serum phosphate concentrations decreased but serum calcium concentrations did not change. The administration of low phosphate or high phosphate diets by gavage allowed an analysis of changes in PTH over a shorter time frame. Administration of a low phosphate diet by gavage was associated with a decrease in PTH and serum phosphate within 15 minutes. Conversely, when uremic rats fed a high-phosphate diet were gavaged with a high-phosphate diet, PTH concentrations increased with modest changes in serum phosphate. The infusion of phosphate into the duodenum of normal rats was associated with a change in PTH concentrations along with changes in serum phosphate.

Phosphonoformic acid, a phosphate uptake inhibitor, when infused into the duodenum also rapidly increased PTH concentrations with no significant changes in serum phosphorus. The intravenous infusion of phosphate to normal rats fed a low phosphate diet was associated with modest increases in serum phosphate and a rapid increase in PTH concentrations. No changes in serum calcium were observed. The infusion of sodium chloride to such rats was not associated with changes in parathyroid hormone. This data would suggest that the parathyroid gland is capable of sensing changes in phosphate concentrations in the absence of changes in 
serum calcium and implies the existence of a phosphate sensing mechanism in the parathyroid gland.

We performed experiments in which intact or parathyroidectomized rats were administered phosphate into the duodenum [11]. In control experiments, an equivalent amount of sodium chloride was administered into the duodenum. We examined changes in the fractional excretion of phosphate in the kidney. We found that in intact rats, the administration of phosphate into the duodenum was associated with a very rapid change in the fraction excretion of phosphorus in the kidney. At the early time points, there were minimal changes in serum phosphorus concentrations. Rats administered sodium chloride did not show a change in the fraction excretion of phosphate. Concentrations of parathyroid hormone, FGF-23 and sFRP-4, factors that are known to increase phosphate excretion in the kidney, did not change despite changes in the fraction excretion of phosphate following the administration of intra-duodenal phosphate. These observations were confirmed by showing that parathyroidectomy did not alter the response to the administration of intra-duodenal phosphate. Thus, the intestine is able to detect an increase in luminal phosphate concentrations (phosphate sensing) and signal to the kidney to increase the excretion of phosphate. We demonstrated that the increase in the fraction excretion of phosphate in the kidney following the administration of intra-duodenal phosphate was not mediated by renal nerves. Homogenates of the intestine infused into rats increased the fraction excretion of phosphate in the kidney demonstrating the presence of a factor within the intestine capable of increasing renal phosphate excretion. The chemical nature of this factor is currently being investigated.

\section{Rapid enteric-renal responses and solute sensing for other ions}

There is evidence that a mechanism similar to that noted for phosphate exists in the case of other ions as well. For example, it is known that natriuretic responses following oral sodium chloride feeding are more marked than the responses seen following the intravenous infusion of sodium chloride, suggesting the presence of both sensing and effector mechanisms in the intestine for sodium [27-30]. Guanylin has been identified as a sodium-specific effector molecule made in the intestine that alters renal sodium transport [31-35]. Gastrointestinal sensing has also been identified in the case of potassium [36-39]. Finally, the calcium-sensing receptor is expressed in the gastrointestinal tract and responds to dietary amino acids [28]. It is possible that there exist enteric-renal signaling mechanisms for a number of solutes besides phosphate.

\section{Concluding remarks and future directions}

Bacteria, yeast, renal and intestinal epithelial cells, osteoblasts and marrow cells respond to alterations in phosphate concentrations in the medium. Parathyroid glands and intestine also appear to sense phosphate concentrations in vivo. It is unknown if the phosphate sensing mechanism in mammalian organisms is a cell surface receptor that binds to phosphate or is an intracellular protein which response to changes in intracellular phosphate concentrations that are produced as a result of changes in the extracellular phosphate. Changes in phosphate in the external medium trigger a series of transcriptional events in bacteria and yeast that enhance or diminish the efficiency of phosphate retention. Changes in the extracellular phosphate concentrations in the medium of epithelial cells enhances or diminishes the efficiency of phosphate uptake by these cells presumably by alterations in the level of expression of sodiumphosphate co-transporters. In the intestine, changes in the extracellular phosphate concentration result in the release of a factor that enters the circulation and alters renal phosphate transport. 
Future experiments will need to be directed at understanding the nature of the phosphate sensing mechanism in mammalian cells and the characteristics of the factor released by the intestine that modulates renal phosphate reabsorption.

\section{Acknowledgments}

Supported by NIH grants DK 65830, DK 76829, DK 77669 and a grant from Genzyme

\section{References}

1*. Berndt T, Kumar R. Phosphatonins and the regulation of phosphate homeostasis. Annu Rev Physiol 2007;69:341-359. This review summarizes new concepts regarding phosphate homeostasis. [PubMed: 17002592]

2. Tanaka Y, Deluca HF. The control of 25-hydroxyvitamin D metabolism by inorganic phosphorus. Arch Biochem Biophys 1973;154:566-574. [PubMed: 4691503]

3. Tanaka Y, Deluca HF. Role of 1,25-dihydroxyvitamin D3 in maintaining serum phosphorus and curing rickets. Proc Natl Acad Sci U S A 1974;71:1040-1044. [PubMed: 4524612]

4. DeLuca HF. Overview of general physiologic features and functions of vitamin D. Am J Clin Nutr 2004;80:1689S-1696S. [PubMed: 15585789]

5. Berndt TJ, Schiavi S, Kumar R. "Phosphatonins" and the regulation of phosphorus homeostasis. Am J Physiol Renal Physiol 2005;289:F1170-1182. [PubMed: 16275744]

6*. Shaikh A, Berndt T, Kumar R. Regulation of phosphate homeostasis by the phosphatonins and other novel mediators. Pediatr Nephrol 2008;23:1203-1210. A clinically oriented review which discusses altered phosphate metabolism in various disease states. [PubMed: 18288501]

7. Sommer S, Berndt T, Craig T, Kumar R. The phosphatonins and the regulation of phosphate transport and vitamin D metabolism. J Steroid Biochem Mol Biol 2007;103:497-503. [PubMed: 17224271]

8. Nishida Y, Taketani Y, Yamanaka-Okumura H, Imamura F, Taniguchi A, Sato T, Shuto E, Nashiki $\mathrm{K}$, Arai H, Yamamoto $\mathrm{H}$, et al. Acute effect of oral phosphate loading on serum fibroblast growth factor 23 levels in healthy men. Kidney Int 2006;70:2141-2147. [PubMed: 17063170]

9. Calvo MS, Kumar R, Heath H 3rd. Elevated secretion and action of serum parathyroid hormone in young adults consuming high phosphorus, low calcium diets assembled from common foods. J Clin Endocrinol Metab 1988;66:823-829. [PubMed: 2831248]

10. Segawa H, Kaneko I, Yamanaka S, Ito M, Kuwahata M, Inoue Y, Kato S, Miyamoto K. Intestinal Na-P(i) cotransporter adaptation to dietary P(i) content in vitamin D receptor null mice. Am J Physiol Renal Physiol 2004;287:F39-47. [PubMed: 14996670]

11**. Berndt T, Thomas LF, Craig TA, Sommer S, Li X, Bergstralh EJ, Kumar R. Evidence for a signaling axis by which intestinal phosphate rapidly modulates renal phosphate reabsorption. Proc Natl Acad Sci U S A 2007;104:11085-11090. A key paper that deals with the sensing of phosphate in the intestine and the releases of an intestinal factor that alters renal phosphate transport. [PubMed: 17566100]

12. Hulett FM. The signal-transduction network for Pho regulation in Bacillus subtilis. Mol Microbiol 1996;19:933-939. [PubMed: 8830274]

13**. Lamarche MG, Wanner BL, Crepin S, Harel J. The phosphate regulon and bacterial virulence: a regulatory network connecting phosphate homeostasis and pathogenesis. FEMS Microbiol Rev 2008;32:461-473. An important review of phospahte sensing in bacteria. [PubMed: 18248418]

14. Tommassen J, Lugtenberg B. PHO-regulon of Escherichia coli K12: a minireview. Ann Microbiol (Paris) 1982;133:243-249. [PubMed: 7044214]

15. Wanner BL. Gene regulation by phosphate in enteric bacteria. J Cell Biochem 1993;51:47-54. [PubMed: 8432742]

$16^{* *}$. Mouillon JM, Persson BL. New aspects on phosphate sensing and signalling in Saccharomyces cerevisiae. FEMS Yeast Res 2006;6:171-176. A key review of phosphate sensing and responses to altered phosphate concentrations in yeast. [PubMed: 16487340]

Curr Opin Nephrol Hypertens. Author manuscript; available in PMC 2010 July 1. 
17. Markovich D, Verri T, Sorribas V, Forgo J, Biber J, Murer H. Regulation of opossum kidney (OK) cell Na/Pi cotransport by Pi deprivation involves mRNA stability. Pflugers Arch 1995;430:459-463. [PubMed: 7491271]

18. Lee DB, Walling MW, Brautbar N. Intestinal phosphate absorption: influence of vitamin D and nonvitamin D factors. Am J Physiol 1986;250:G369-373. [PubMed: 2420210]

19. Rizzoli R, Fleisch H, Bonjour JP. Role of 1,25-dihydroxyvitamin D3 on intestinal phosphate absorption in rats with a normal vitamin D supply. J Clin Invest 1977;60:639-647. [PubMed: 893667]

20. Fujita T, Izumo N, Fukuyama R, Meguro T, Nakamuta H, Kohno T, Koida M. Phosphate provides an extracellular signal that drives nuclear export of Runx2/Cbfa1 in bone cells. Biochem Biophys Res Commun 2001;280:348-352. [PubMed: 11162521]

21. Goseki-Sone M, Yamada A, Asahi K, Hirota A, Ezawa I, Iimura T. Phosphate depletion enhances tissue-nonspecific alkaline phosphatase gene expression in a cultured mouse marrow stromal cell line ST2. Biochem Biophys Res Commun 1999;265:24-28. [PubMed: 10548485]

22. Goseki-Sone M, Yamada A, Hamatani R, Mizoi L, Iimura T, Ezawa I. Phosphate depletion enhances bone morphogenetic protein-4 gene expression in a cultured mouse marrow stromal cell line ST2. Biochem Biophys Res Commun 2002;299:395-399. [PubMed: 12445813]

23. Almaden Y, Canalejo A, Ballesteros E, Anon G, Rodriguez M. Effect of high extracellular phosphate concentration on arachidonic acid production by parathyroid tissue in vitro. J Am Soc Nephrol 2000;11:1712-1718. [PubMed: 10966496]

24. Almaden Y, Canalejo A, Hernandez A, Ballesteros E, Garcia-Navarro S, Torres A, Rodriguez M. Direct effect of phosphorus on PTH secretion from whole rat parathyroid glands in vitro. J Bone Miner Res 1996;11:970-976. [PubMed: 8797118]

25. Almaden Y, Felsenfeld AJ, Rodriguez M, Canadillas S, Luque F, Bas A, Bravo J, Torregrosa V, Palma A, Ramos B, et al. Proliferation in hyperplastic human and normal rat parathyroid glands: role of phosphate, calcitriol, and gender. Kidney Int 2003;64:2311-2317. [PubMed: 14633156]

26. Martin DR, Ritter CS, Slatopolsky E, Brown AJ. Acute regulation of parathyroid hormone by dietary phosphate. Am J Physiol Endocrinol Metab 2005;289:E729-734. [PubMed: 15914507]

27. Carey RM. Evidence for a splanchnic sodium input monitor regulating renal sodium excretion in man. Lack of dependence upon aldosterone. Circ Res 1978;43:19-23. [PubMed: 657455]

28. Conigrave AD, Brown EM. Taste receptors in the gastrointestinal tract. II. L-amino acid sensing by calcium-sensing receptors: implications for GI physiology. Am J Physiol Gastrointest Liver Physiol 2006;291:G753-761. [PubMed: 17030896]

29. Lennane RJ, Carey RM, Goodwin TJ, Peart WS. A comparison of natriuresis after oral and intravenous sodium loading in sodium-depleted man: evidence for a gastrointestinal or portal monitor of sodium intake. Clin Sci Mol Med 1975;49:437-440. [PubMed: 1192701]

30. Lennane RJ, Peart WS, Carey RM, Shaw J. A comparison on natriuresis after oral and intravenous sodium loading in sodium-depleted rabbits: evidence for a gastrointestinal or portal monitor of sodium intake. Clin Sci Mol Med 1975;49:433-436. [PubMed: 1192700]

31. Hill O, Kuhn M, Zucht HD, Cetin Y, Kulaksiz H, Adermann K, Klock G, Rechkemmer G, Forssmann WG, Magert HJ. Analysis of the human guanylin gene and the processing and cellular localization of the peptide. Proc Natl Acad Sci U S A 1995;92:2046-2050. [PubMed: 7892222]

32. Cetin Y, Kuhn M, Kulaksiz H, Adermann K, Bargsten G, Grube D, Forssmann WG. Enterochromaffin cells of the digestive system: cellular source of guanylin, a guanylate cyclase-activating peptide. Proc Natl Acad Sci U S A 1994;91:2935-2939. [PubMed: 8159683]

33. Currie MG, Fok KF, Kato J, Moore RJ, Hamra FK, Duffin KL, Smith CE. Guanylin: an endogenous activator of intestinal guanylate cyclase. Proc Natl Acad Sci U S A 1992;89:947-951. [PubMed: 1346555]

34. de Sauvage FJ, Keshav S, Kuang WJ, Gillett N, Henzel W, Goeddel DV. Precursor structure, expression, and tissue distribution of human guanylin. Proc Natl Acad Sci U S A 1992;89:9089_ 9093. [PubMed: 1409606]

35. Hamra FK, Forte LR, Eber SL, Pidhorodeckyj NV, Krause WJ, Freeman RH, Chin DT, Tompkins JA, Fok KF, Smith CE, et al. Uroguanylin: structure and activity of a second endogenous peptide that stimulates intestinal guanylate cyclase. Proc Natl Acad Sci U S A 1993;90:10464-10468. [PubMed: 7902563] 
36. Rabinowitz L, Green DM, Sarason RL, Yamauchi H. Homeostatic potassium excretion in fed and fasted sheep. Am J Physiol 1988;254:R357-380. [PubMed: 3344840]

37. Rabinowitz L. Aldosterone and potassium homeostasis. Kidney Int 1996;49:1738-1742. [PubMed: 8743488]

38. Rabinowitz L. Model of homeostatic regulation of potassium excretion in sheep. Am J Physiol 1988;254:R381-388. [PubMed: 3344841]

39*. Lee FN, Oh G, McDonough AA, Youn JH. Evidence for gut factor in K+ homeostasis. Am J Physiol Renal Physiol 2007;293:F541-547. An important paper that suggests the presence of a gastric factor involved in potassium homeostasis. [PubMed: 17522262] 